\title{
LA NOCHE DE LOS JABALÍES
}

\author{
Night of the boar
}

\section{Henry Sevilla Morales*}

Gerardo Tenorio supo que el ángel de la muerte por fin lo había alcanzado; husmeó suavemente con los dedos bajo su vientre, y acarició la tibiez de la sangre rezumada. Volvió a sentir un ligero mareo, se columpió un poco, y con fuerza bárbara empujó la lanza que tenía ya embutida entre las entrañas, para asegurarse de que esta vez no estuviera dentro de un sueño; el acero de la hoja traspasó las vísceras, hasta salir como un arpón hambriento sobre su espalda. Sintió un poco de dolor, pero no quiso molestarse en lanzar siquiera un quejido, porque no quería interrumpir el silencio brujo que se desgarraba en medio de las fauces del Volcán.

Mientras Gerardo agonizaba entre ligeros resuellos, recordó tanto los mejores como los peores momentos de su vida, y no pudo saber si estos habían ocurrido hacía años, o hacía siglos infinitos en el indescriptible delirio de aquel jueves de terror y sombras. Volvió a sentir el filo del acero sediento en el gorgoriteo de sus vísceras, y pensó en las veces que esa misma lanza le había abierto el pecho a tantos jabalíes en la bocaza oscura de la selva, y se dio cuenta de que morir era vivir el drama de la vida entera en tan solo unos segundos, que podrían ser milenios, pues el tiempo es lo más impalpable que hay en este mundo de fantasías y ensueños.

El Volcán lanzó un rugido, y corrieron los primeros vientos vespertinos desde la ribera del crique. La tarde se despedía con un garbo multicolor entre las nubes que avanzaban perezosas e indiferentes hacia el oeste, y Tenorio comprendió que había llegado el momento de entregarse a la inexorable ley de la naturaleza; sintió por última vez una paz muy parecida a la que experimentaba en las alucinaciones, que desde siempre lo concurrieron, y comprendió que su vida entera había sido solamente una premonición

\footnotetext{
* Docente Universidad Estatal a Distancia, Costa Rica. 
de ese momento fantástico e inasible que ahora se hallaba viviendo. Desde lo alto de un árbol de cortés, un ronco curré entonó un Réquiem que, de un tajo, terminó con la respiración estertorosa de Tenorio. Entonces su cuerpo se volvió un oscuro leño inerte y, sin cerrar sus ojos de gato brujo, se quedó dormido, trágicamente dormido.

$$
* * * * * *
$$

Era un Jueves Santo. Gerardo Tenorio estaba terminando de darle los últimos retoques al filo del puñal cuando, al pie de los naranjos musgosos, en el propio patio de su casa, vio la silueta en movimiento de un jabalí cariblanco. Gerardo reptó hasta donde tenía la lanza, la tomó y regresó de inmediato por el animal, con el corazón exaltado. Buscó alrededor con la mirada, pero no pudo encontrarlo; miró fugazmente en dirección hacia el crique, pero tampoco pudo verlo. Entonces tendió la mirada hacia donde menos le gustaba mirar, y vio cómo el animal caminaba parsimoniosamente hacia el Cementerio de los Indios. Entonces se le esfumó todo vestigio de sed de cazador.

El Cementerio de los Indios era un lugar prohibido para todos en la aldea. Había demasiadas historias de gente que desaparecía de sus casas, y que era encontrada años después, convertidos en una osamenta quebrantada en los alrededores de las chozas abandonadas, pero solo hasta que a los espíritus del bosque se les antojara; o de mujeres asediadas por una peste de sarna, cuyos vientres se llenaban de un brote sanguinolento que, al cabo de pocas semanas, terminaba por llenarlas de todo tipo de infecciones de la piel, hasta que no amanecían en las chozas y eran luego encontradas al fondo de un barranco, cerca del lugar de los indios. Incluso hubo quien en alguna ocasión aseguró haber visto a una Cegua Mocuana-o Tzegua Mocuana, como a muchos todavía les gustaba llamarla- que desenterraba a los muertos debajo de las cocinas de las chozas, para extraer una sanguaza amarillenta entre los huesos astillados. Verdaderamente, era un lugar que solo terror y alucinación inspiraba.

Gerardo Tenorio era un aficionado de la muerte, por así decirlo. No le importaba si el animal era pequeño o grande, peligroso o inofensivo; el caso era matar, incrustar el puñal o la lanza sobre cualquier tejido o cuero, pero matar. Esta vez prefirió ni siquiera pensar en la posibilidad de seguir su empresa. Sentía miedo.

El hombre se sentó en una piedra negra frente a la entrada de su choza, y se puso a juguetear con el filo de la lanza, pasándolo por los callos ásperos de las palmas, y recordó que sus amigos: el sordo Joaquín Maltés y el carnicero Rodolfo Miranda, no demorarían en pasar por él, y se sintió muy perturbado. En el aire estival se respiraba todavía el vaho de calor que dejaba el sol de Semana Santa; el viento se había detenido y, tras la cresta crispada del Volcán, el sol dejaba una sombra negra que iba bajando como un lúgubre manto sobre el caserío. A lo lejos, Gerardo Tenorio escuchó las voces de sus dos compañeros de caza, pregonando con júbilo que al otro día se les iba a reventar la tripa de comer carne, y gritando que sólo los hombres flojos se quedaban esperando en casa: que el alimento les bajara del cielo.

Los tres amigos llegaron puntuales a la choza de Tenorio, con una alegría que solo con amigos de toda la vida se puede desarrollar; y sin darle ocasión al otro para cavilaciones de ningún tipo, le mostraron las nuevas lanzas que habían estado fabricando desde la última vez que fueron de cacería, pues Miranda había opinado que necesitaban una hoja de puñal más larga y con menor grosor para una estocada más certera y mortal. Los tres eran grandes conocedores: tanto de la anatomía como del comportamiento social de los jabalíes; sabían que esos animales eran muy sedentarios de día, pero que de noche se desplazaban en pequeñas o grandes piaras, y que en la época seca se aglomeraban por decenas, alrededor de barrizales o pantanos para tomar baños con un protocolo casi religioso, los cuales tienen funciones que van desde la regulación de la temperatura durante el día, hasta la incitación sexual durante la época de celo. Los hombres conocían bien que los animales son generalmente matriarcales, y que especialmente durante los meses de marzo y abril, época durante el cual las hembras están habilitadas, su perímetro de desplazamiento se vuelve más 
reducido, incluso durante la noche. A pesar de su conocimiento en la materia, los hombres sabían que una piara de estos animales enfurecidos era más peligrosa que cualquier otra manada de animales salvajes y que, aunque los jabalíes no pueden mantener una velocidad constante por mucho tiempo, el poder triturador de sus dentaduras era simplemente aterrador. Conocían muchas historias de cazadores que nunca habían regresado a sus casas, y que igual que ocurría con la gente del Cementerio de los Indios, sus huesos habían sido encontrados tiempo después, pero por accidente, y astillados por los colmillos feroces de las bestias; esparcidos a lo largo de la maleza de la selva.

La táctica de cacería de estos tres hombres consistía más en un ritual de matanza desenfrenada que en cualquier otra cosa. Se trataba de espiar sigilosamente a una piara, agazapándose detrás de los matorrales, o encaramados en algún árbol frondoso en las cercanías del río, hasta que sus oídos diestros y sus miradas de gatos detectaban a los jabalíes. Una vez localizada la piara, Joaquín Maltés y Rodolfo Miranda buscaban la forma de sitiarlos, hasta tenerlos, de alguna forma, rodeados, para dejar que Gerardo Tenorio se les enfrentara cuerpo a cuerpo con su lanza, que ellos mismos fabricaban, incrustándoselas impetuosamente en el pecho. Luego se le unían los otros y, con su descomunal fuerza, dejaban el suelo hecho un barrizal de sangre; entre gruñidos moribundos y el gorgoriteo humeante que salía a raudales de los pechos de los animales. Muchas veces comenzaban por herir algún jabato, para provocar la furia de las madres, y de ese modo empezar la matanza que terminaba con al menos tres jabalinas cargadas en el lomo de los caballos, y con algunas otras mal acuchilladas, que huían luego de ver a la piara derrotada por el acero y la barbarie. Solamente, en caso de extremo peligro, echaban mano los hombres a sus revólveres calibre 38, que llevaban casi siempre de adorno, pues se trataba de matarlos a pura lanza, con sus propias manos, de modo que el olor a sangre con barro y almizcle se mezclaran con los bramidos de los animales, y que de ese modo se perpetuara una conducta ya arraigada en lo profundo, en lo verdaderamente primitivo del alma.
Así era todos los meses desde que los tres cazadores firmaron un pacto para desangrar a la fauna del Volcán. Aquel era el tiempo cuando el Volcán ofrecía una exuberancia de animales silvestres, que iban desde grandes felinos como: el Puma, el Jaguar, el León Breñero y el Caucel; o hermosas aves como: las Pavas Crestadas, el Rualdo (cuando todavía no había perdido la voz) el Pájaro Campana, y el más solemne de todos: el Quebrantahuesos. Era un tiempo de abundancia vulgar, donde la flora era un mosaico hermosísimo de orquídeas, heliconias, helechos, bromelias y marantáceas: infinidad de flores silvestres, en cuyos pistilos posaban sus picos finos los colibríes de los más alucinantes colores y tamaños; y de árboles de madero, cortés, espavel, zapote, laurácea, maría. Pero, los hombres no sabían que la selva se estaba preparando para verlos morir de espanto y locura, condenados por sus propias alucinaciones, en el vertiginoso ciclo que es la maldición de la naturaleza.

$* * * * *$

Con las primeras sombras de la noche, los tres hombres partieron hacia la muerte, azorados por el olor inconfundible a caballo sudado y a pólvora, por el brillo de la punta de las lanzas, y por la costumbre pura de matar todo lo que respirara y se moviera, incapaces de vislumbrar la tragedia que estaba por desatarse en la bocaza oscura de la jungla. Se hundieron entre las garras alargadas de las sombras de un platanal abandonado, bajo el ambarino de la luna, que se levantaba ya a sus espaldas, llenando el paisaje de un brillo no menos que fantasmagórico. Los tres bordearon la garganta del inmenso río, que rugía potente y que ensordecía el resoplar de las bestias; y luego bajaron por el Desfiladero del Castillo, pasando por chaparrales espinosos y luego en medio de angosturas de la selva casi virgen. Al llegar al llano, la noche se atestó de un coro de grillos que depositó un horrible augurio en el alma de Tenorio; el bosque se quedó como dormido, lóbrego.

Los hombres llevaban ya unas dos horas de haber descendido por el Desfiladero del Castillo, cuando se dieron cuenta de que la selva les había robado la voz. Eran tal vez las nueve 
de la noche, y Gerardo Tenorio tuvo el valor de interrumpir el silencio de los tres.

- Hermanos, -balbuceó, con su voz de lija-, este asunto no me está gustando nada. Siento como que llevamos al Diablo en las espaldas.

Hubo un silencio largo. Ni Maltés ni Miranda pronunciaron palabra. Una parvada de imágenes difusas empezó a acosar la mente de Tenorio. Se sintió mareado, con la vista un tanto nublada, y vio tres rayas amarillas atravesársele en el camino. Cerró los ojos por un instante, sacudió la cabeza y, al abrir los ojos, se encontró en medio de aguas turbulentas, vadeando contra la corriente de un río que estrellaba pedregones negros contra el pecho de su caballo; tuvo la impresión de estar soñando, pero las imágenes eran tan vívidas que se empezó a confundir. Escuchó una orquesta de voces quejumbrosas bajo las lenguas enfurecidas del río, y cuando bajó los ojos hasta sus piernas, miró que las tenía llenas de heridas escabrosas, y que la crin del caballo se había transformado en los bucles de una cabellera femenina de la más divina belleza. La cabellera resbalaba portentosamente hasta la mitad del cuello del caballo, y luego se derritió en una miel brillosa y blanca que se mezcló con los bramidos del río y de las voces; tendió la mirada hacia atrás, río abajo, y vio cómo entre la miel y el agua se erigía un enorme árbol, de cuyas raíces salían todo tipo de insectos maléficos, armados de aguijones y tenazas, que se incrustaban en su espalda como sanguijuelas hambrientas, que le causaron alucinaciones imposibles de describir, pero que luego se volvían una seda multicolor que desprendía una suave melodía con cuyas tonadas se iba adormilando el espíritu trastornado de Tenorio. Lleno de una paz inexplicable, y luego de lo que le parecieron horas-años, quizáde encanto, dentro de ese mundo de música arcangélica, el hombre miró hacia delante y vio que los pedregones, las lenguas y las voces bajo el agua habían desaparecido para dejar frente a sus ojos un arroyo diáfano que se abrió en dos como una puerta mágica. Hacia él cabalgó Tenorio y en segundos todo su recuerdo se perdió en una nube azul que le borró toda noción de tiempo y espacio.

Luego de lo que parecieron años de sueño, volvió a verse sobre la lobreguez del llano, con sus bestias y sus lanzas, y Maltés y Miranda iban cabalgando en silenciosa marcha hacia el lugar de los jabalíes, y se sintió invadido por un delirio vertiginoso. Poco a poco se le fueron borrando las imágenes de la visión que acababa de tener y la mente pareció quedársele muy adormilada, dejándole solo una manía por mirarse las piernas y las crines de los tres caballos que los cargaban.

Cuando finalmente llegaron al lugar de los jabalíes, los tres hombres iban ya con el alma perturbada, como si por primera vez presintieran los alones de la muerte rondarles las espaldas. Apersogaron las bestias en un árbol de guayabo, a varios cientos de metros de una planicie cenagosa, por donde sabían que los jabalíes se desplazaban en pequeñas piaras, triscando entre gruñidos y mordiscos que, en circunstancias distintas, les parecían muy apetecibles. Caminaron sagaces, en lobuzna postura y con el corazón alterado, empuñando las lanzas en sus manos y sintiendo un hálito místico en el silencio del bosque. Tenorio miró la posición de la luna y supo que eran ya pasadas las once de la noche.

Los hombres llevaban ya puestas las linternas de cacería, atadas alrededor de sus cabezas. Llevaban también los revólveres fajados al cinto, y también puñales para degollar las presas una vez acometida la estocada; pero sus corazones daban poderosas campanadas y las sienes estaban a punto de estallarles, del miedo. Siguieron avanzando en medio de los espinos de lavaplatos y matorrales de lengua de vaca, luego entre cortezas desprendidas de árbol de caucho, y luego sobre barrizales de poca profundidad, hasta que se vieron de pronto al borde de un barranco cascajoso. Los hombres tuvieron la pavorosa conciencia de que estaban perdidos, literalmente. Conocían la selva mejor de lo que conocían sus corazones, pero nunca habían visto ese abismo que se precipitaba infinito a sus pies.

- $\quad$ ¡Estamos jodidos, hombre! Ahora sí que nos llevó el Diablo- dijo el sordo Maltés, 
con la voz y el espíritu apagados. - Esto sí que se está poniendo feo. Hace rato siento que El Malo nos sigue los pasos.

- Yo también, hombre, -respondió Tenorio, con las manos sudorosas. - ¿Por qué no nos dejamos de carajadas y regresamos ya mismo? La cosa ya no me está gustando.

Maltés lo escuchó, más bien, lo miró, con su infalible capacidad de leer los labios, y asintió con la cabeza. Miranda los observó fijamente a los ojos y, a pesar de tener también él los nervios desvencijados, se limitó a pronunciar un largo silencio, y con ello les dejó saber que no estaba dispuesto a dejarse acobardar por estupideces de la imaginación. Así que siguió su camino sobre el borde del barranco, hacia el oeste. Tenorio y Maltés le siguieron el paso, pero tan pronto como habían reanudado el viaje, los hombres tuvieron la impresión de haber estado caminando en círculos, sintiéndose todavía más extraviados. Sintieron un olor fuertísimo y hostigador, como una combinación de azufre, almizcle y sangre coagulada, y vieron escasamente la silueta de un animal que se perdía en la maleza. Le siguieron a pesar del miedo, motivados por ese instinto frenético que solo en los cazadores y en los locos puede desarrollarse con tanto ahínco, y que puede vencer la fuerza de cualquier tipo de premonición. Miraron al animal correr juguetonamente, despacio y como si les invitara a seguirlo. Corrieron tras él, desesperados, y, mientras más le perseguían, el miedo se fue disipando hasta que fue transformándose en un alocado frenesí. Pero, este frenesí pronto se les volvió a transformar en miedo, al ver que el animal parecía llevarlos hacia algo desconocido y funesto, hasta que se dieron cuenta de que habían estado corriendo tras él por mucho tiempo.

El animal desapareció. Los hombres se detuvieron frente a un caserío abandonado, respirando a bocanadas, exhaustos y aturdidos, y vieron que estaban en medio de lo que creyeron sería El Cementerio de los Indios. Nunca antes lo habían visto. Allí el paisaje era sencillamente tétrico. Las chozas abandonadas estaban llenas de un moho verduzco, y despedían un olor irreconocible que les llenó las entrañas de náuseas. Se escuchaba todo tipo de ruidos salir debajo de la tierra, y el aire se llenaba de un viento frío que les golpeaba la cara como un látigo fantasmal. El suelo estaba poblado de decenas de huesitos quebrados por las mandíbulas de alguna poderosa bestia, y los congos aullaban como azuzados por una fuerza maléfica, mutilando el poco valor que en algún rincón del alma le quedaba a Tenorio. En medio de la tierra se levantó un revuelo de hojas secas y la noche se volvió más oscura, pero para desgracia de los hombres, sus miradas se llenaron de una nitidez cromática que les agudizó la vista y pudieron ver toda clase de espantos que se arrastraban hacia ellos, que se encontraban como maniatados, más bien inmóviles, mientras una danza satánica, practicada por los espíritus, les rodeaban por la cintura y les besaban en el cuello, luego en los labios, en la espalda... les manoseaban los testículos, y se reían a carcajadas de sus caras estupefactas, llenas de un lagrimeo helado. Maltés, que desde hacía muchos años había perdido el sentido del oído, pudo en ese momento escuchar los sonidos más infernales que ningún ser humano pudiere haber imaginado. El bosque se quedó mudo una vez más.

El primero en darse cuenta de que la hora de su fin había llegado fue Miranda, cuando, luego de un largo tiempo de alucinación e inmovilidad sobre la osamenta, sintió la tibiez de la mierda correrle entre las piernas. No tuvo tiempo de sentir vergüenza, pues allí mismo lo invadió una terrible convulsión que terminó en un vómito, que acabó por ahogarlo, mientras sus compañeros lo miraban inmóviles, mareados de asco y espanto, al notar cómo se ahogaba en su propia babaza, echando coágulos de una sangre negruzca que pronto le dejaron quieto entre el soplar del viento y los bramidos de los congos, que reanudaron la orquesta, hasta que los últimos estertores fueron desapareciendo, dejando al hombre despedirse para siempre del mundo de los vivos.

Tenorio y Maltés siguieron inmóviles por algún tiempo, aferrados a las lanzas, que estaban bañadas de un sudor frío que parecía más bien un llanto triste. Fue durante ese trance de ilusión, terror y petrificación, cuando escucharon a la 
piara que se les aproximaba con ávida violencia. Un monzón de adrenalina los despertó del sueño y los puso frente a frente con los animales. Parecieron recobrar el juicio repentinamente, e instantes después, se vieron luchando con desespero, incrustando las lanzas en los cuerpos de los jabalíes, que se abalanzaron contra ellos, en una venganza largamente anhelada. Tenorio y Maltés se encontraban frente al desfiladero de la locura, pero empuñaron las lanzas con más ímpetu que nunca, impulsados por las más violentas fuerzas que habitan el primitivismo del ser humano: el instinto de supervivencia y el instinto de matar.

Lucharon como valientes guerreros; primero con sus lanzas, que clavaron diestramente en los cuerpos de los jabalíes, luego con sus revólveres 38, y cuando las balas se les acabaron, pelearon con los puñales; pero los jabalíes eran demasiados. Se habían desatado como una marabunta de colmillos y furia, y empezaron a acercárseles hasta dejarlos rodeados; acorralados entre un paredón encajonado alrededor del Cementerio de los Indios y un río turbulento que notaron por primera vez cuando, en medio de la desesperación, intentaron correr por sus vidas. Tenorio pudo ver cómo un grupo de unos cinco jabatos mascullaban el cuerpo inerte de Miranda, y entre rugidos y locura, supo que el poder de la naturaleza es sencillamente paranormal. Deseó por primera vez, en su vida, haber podido creer en algo, en lo que fuese; quiso despojarse de su soberbia y suplicar por su vida, pero había nacido para creer en cualquier cosa, menos en las Fuerzas Celestiales. Recordó que de niño quedó huérfano tras la muerte de sus padres en la guerra, y que se había aislado del mundo civilizado por muchos años antes de llegar a vivir solo en la aldea, viviendo del bosque y de su invencible capacidad para aguantar hambre; que desde que descubrió el potencial atroz del hombre para engendrar la muerte, sus manos no habían descansado en el afán de matar todo cuanto tuviera movimiento y que no perteneciera al eslabón supremo de los que nacieron humanos; que antes de ser cazador, había sido carnicero profesional; que tras su estocada habían muerto centenares de vacas, terneros, toros de los más fieros, cerdos, gallinas: de todo... Que el impulso de matar no es menor, en ninguna medida, que el impulso de sobrevivir, o que el impulso de soñar o de volverse loco. Supo, finalmente, que la vida es una vorágine de suplicios y traumas, donde pocos se salvan de las fauces de la soledad y del miedo, y que quienes por alguna extraña casualidad escapan a esa maldición, viven condenados al limbo infinito de los que no viven, de los que no son, de los que ignoran los deleites de la locura y del contacto con las fuerzas de lo tétrico y lo paranormal...

Tenorio sintió un extraño júbilo. Entonces pensó que era cien veces preferible morir lleno de espanto que morir cuando no se había vivido nunca. Ese fue su consuelo, y se hizo a la idea de que pronto moriría. Pero no fue así.

Los jabalíes se acercaron lentamente, como conspirando un plan estrictamente sobrenatural. Los rugidos pronto empezaron a parecer los bramidos de mil toros enloquecidos, y la selva seguía aullando como azuzada por la voz del diablo. Los congos brincaban por las ramas de los espaveles, meneándolas con fuerza barbárica y maléfica, y los hombres terminaron de perder las esperanzas. Justo en ese momento, Tenorio tocó por accidente el tronco de un árbol de guayabo que no había visto en la claridad de la noche, y lo trepó con una agilidad felina. Llamó a Maltés, quien estaba a punto de desmayarse del terror, casi rodeado por completo por la piara. Pero, Maltés era sordo, y no pudo escuchar el llamado del amigo que, con horrible desesperación, tuvo que observar el episodio donde decenas de jabalíes se disputaban por devorarlo como a un muñeco indefenso. Desde lo alto, Tenorio vio a un grupo de jabalíes morder el tronco del guayabo, como si quisieran rasgarlo y derribarlo con las puras fauces. Los miró con asombro, llenos todos de una sed de sangre que ni él mismo, en sus mejores tiempos de cacería, hubiere soñado poseer; mascaron y golpearon el tronco, entre bramidos y resoplos, tanto que Tenorio se olvidó de su compañero y cuando trató de buscarlo con la mirada, no pudo distinguirlo en medio del fango, los aullidos de los congos y los jabalíes aglomerados, 
como una manada de lanzas, colmillos y furia, precipitados todos, enloquecidos, sobre el cuerpo ya inerte de Maltés.

Tenorio sabía que estas bestias eran de una naturaleza simplemente neurótica, pero aquello era más de lo que hubiere podido imaginar. Incluso sabía que sus parientes cercanos, los cerdos, eran capaces de las más abominables escenas. Los había visto comerse docenas de pollos vivos en el patio de las chozas, sabía de una historia cuando un cerdo enorme se había comido a un niño que dormía en una hamaca, mientras sus padres trabajaban en el campo; sabía incluso de dos cerdos que habían devorado a una anciana enferma en una isla lejana durante un vendaval; y los había visto pelear como bestias endemoniadas por los desperdicios en sus canoas, agarrándose a dentelladas, sangrándose los hocicos los unos con los otros... Pero, nada de eso era comparable con el instinto sanguinario de esta piara de los infiernos que tenía a sus pies. Tenorio se sintió exhausto, y el cuerpo se le empezó a aflojar como una armazón de carne cansada y flácida.

Permaneció en el guayabo por largas horas-o al menos eso le pareció. Sintió que un sueño irresistible le recorría el cuerpo. La espalda se le fue durmiendo y los párpados caían como dos ventanas pesadas y llorosas. Se recostó en una horqueta del guayabo, y miró al cielo con los ojos devastados. La luna ya se ocultaba, lúgubre y cómplice, tras las sombras de dos nubarrones oscuros. Los congos habían callado y el río que por instantes tuvo a sus espaldas mientras la piara le rodeaba, se había desvanecido como en un soplo de artificio y silencio. Ya no podía escuchar los bramidos de las bestias ni la burla de los congos sobre las altas ramas, y sintió que era hora de dormir eternamente. Se recostó sobre la horqueta, que le pareció el suave lecho donde nunca descansó su cuerpo, y se deslizó por el placentero reino de Morfeo.

En lo que le pareció un año de sueño, pudo descansar el cuerpo y la mente de una manera que nunca antes había podido, y en los pocos momentos de lucidez que creyó haber tenido durante el sueño, pensó que la muerte es algo deleitable. Vio que es un mundo blanco y sin espantos ni demonios, sin soledad, sin hambre y sin insomnio; que es una hipnosis, apenas poco menos placentera que el sueño recurrente de volar sobre vastos llanos; que es un reino donde miles de fuentes de encanto brotan desde la tierra hinchada de fertilidad; que los volcanes son majestuosos senos de mujer encinta, llenos de una energía bravía que da vida al mundo, que mueve el ciclo voraz e infinito de la vida sobre la tierra. Vio que la tierra es bella, que huele a mujer amorosa, a vientre de ninfa y a aliento de ángel enamorado; que tiene manos de rosa y alma de madre guerrera; que es un lugar donde las aves no tienen miedo, donde nada está maldito, donde los sueños son solamente algo que no existe, pues los sueños son la vida, la misma vida son los sueños... Fue un año mágico, lleno de luz y de una paz que hasta su corazón turbulento pudo disfrutar con un júbilo más que supremo, y que terminó cuando abrió los ojos y se encontró boca abajo, tirado en el suelo, al pie del guayabo, ante un silencio que, aunque total y un tanto desolador, no le provocó mayor incomodidad que el leve dolor que sentía en el pómulo, producto de la caída del guayabo.

En esa posición permaneció largo rato, cansado todavía, pensando que hacía un año había vivido o soñado una tragedia que extrañamente ya no le causaba terror. Estaba hechizado por el sueño del que poco a poco iba despertando, y que poco a poco iba olvidando, como quien, inevitablemente, luego de largos años, olvida-o cree olvidar- el dolor que le ha provocado una tragedia inmensa.

Así, Tenorio fue recobrando el juicio, olvidando la muerte a la que se había entregado, pero de cuyo lecho fue desterrado, rechazado, casi escupido, como una progenie despreciada por la maldición de su propia naturaleza. Aún se hallaba inmóvil, aún conservaba la paz-o más bien el adormecimiento- que en el cuerpo le dejó su intento de muerte, pero la vista empezó a esclarecérsele y empezó a sentir un tibio lagrimeo que descendía a chorritos hasta la barbilla. Empezó a caer una llovizna fría que rápidamente se convirtió en aguacero. Eso lo despertó por completo, le devolvió la condenación de la que tanto creía gozar, y se topó con la realidad que 
había olvidado hacía muy poco. Los jabalíes se habían marchado, los congos se habían callado y la luna se había ocultado. Era de noche todavía, pero calculó que el alba estaba a punto de imponerse sobre las sombras de la madrugada. Se puso en pie y buscó a Maltés, embargado por una sobriedad no menos aterradora que su propia existencia.

Un carámbano de miedo se le atragantaba en el corazón. Se sentía débil, viejo, desgraciado. Miró los jabalíes muertos, algunos todavía luchando contra el estertor de la muerte; otros, con el cuerpo tibio, pero el corazón detenido por las estocadas de las lanzas. Pudo verlos claramente, con la primera claridad del alba, que se colaba entre las gotas que se encharcaban sobre el suelo maldito de la selva, y por primera vez en su vida se supo un ser despreciable. Había tal vez más de veinte jabalíes muertos, que poblaban el suelo de sangre, lodazal y tragedia. Pudo ver el cuerpo de Miranda entre los animales; deforme, mutilado. Caminó hacia atrás, y trastabilló con algo blando y acuoso bajo sus pies: eran las tripas de Maltés; embarrialadas y arrancadas bestialmente de su cuerpo ahora irreconocible, junto al cual se hallaban varios jabalíes muertos y otros tantos: medio muertos.

Gerardo Tenorio se quedó en silencio por unos instantes, y tomando una de las lanzas que desenterró de las ciénagas, arrancó a correr hacia donde creyó lo llevaría de regreso a su casa. Olvidó por completo que habían llegado a caballo y también olvidó que se encontraba en el Cementerio de los Indios. Corrió desesperado, bramando a toda fuerza, con la luz de la mañana que se levantaban por los cerros, al otro lado del Cementerio, y con el cuerpo cargado de años. Por su mente cruzaban las más macabras imágenes y se llenó de una esquizofrenia sencillamente impostergable.

En lo que le parecieron solamente minutos, Gerardo estaba casi en los linderos del caserío de donde la tarde anterior había partido con sus amigos en busca de jabalíes. Frente a sus pies se abría una senda ancha y llena de huellas frescas de paquidermos, inevitablemente: jabalíes.

Miró el despojo que se enfilaba a ambos lados del camino y aquello le pareció apocalíptico, como si una manada de elefantes hubiera hecho una maratón enloquecida, aplastando todo a su paso, llenando el paisaje de una lobreguez indescriptible. La lluvia seguía cayendo y la mañana había aparecido ya por completo a lo ancho y largo del campo, que galanteaba entre espinos y montes verde-azulados; montaña abajo. Pero, Tenorio no pudo apreciarlos; sentía que algo desde lo profundo del ser le martilleaba en el cerebro, y que las sienes estaban a punto de reventarle de los aguijonazos que le llenaban de más y más trastorno. Cuando pudo finalmente divisar el pueblo a los pies del Volcán, miró que las chozas de paja habían sido arrasadas por completo. Se detuvo a pocos metros de la aldea y pudo divisar la tragedia con una nitidez abrumadora. Vio cadáveres de hombres, mujeres, gallinas, cerdos, perros, ancianos y niños; todos mutilados por la furia de la naturaleza. Por doquier sentía el olor a almizcle de jabalí, mezclado con el olor a pólvora y ciénaga que llevaba metido en los pulmones desde que sintió que caminaba en círculos. Se sentó en una piedra con el alma hecha un ascua de desgracia y alucinación. Lloró con amargura por horas, miró la aldea devastada y recordó la noche de delirio que recién había terminado.

Se quedó inmóvil una vez más, detestando el olor que se desprendía de la aldea y de su memoria. A sus pies tenía todavía la lanza que había recogido del fango cuando se encontró parado sobre las tripas de Maltés, y la empuñó con fuerza. Se puso en pie, y empezó a dar estocadas al aire con la lanza. Bordeó toda la aldea, pasando sobre los cadáveres, clavando la lanza en las entrañas de la nada, débil, obsesionado, loco.

Ya era Viernes Santo. La lluvia amainó y el sol empezó a clavar los dientes sobre el caserío desprovisto de vida, pero a pesar del calor y la debilidad, Tenorio se seguía arrastrando como un animal sigiloso por los escombros de la aldea, en la misma pose lobuzna, haciendo los mismos movimientos con la lanza. No sería sino hasta casi medio día que las fuerzas de su cuerpo lo abandonaron, y se quedó inmóvil sobre el cuerpo de alguien quien en vida, calculó, podía haber sido amigo suyo. Allí se quedó el cazador, 
casi inerte, con el corazón apenas latiendo; deshidratado por el sol, por la noche y por el llanto que no le había cesado desde que vio su aldea reducida a ruinas.

Despiértese, Don Tenorio, le dijo un hombre joven, vaciándole un guacal de agua fría en la cabeza. - Hace días que anda como loco con esa lanza en las manos. A ver, deme eso, se está trastornando, amigo.

Eran más de trescientos jabalíes-, balbuceó Tenorio acariciándose el pómulo, que aún le dolía por la caída del guayabo. - Más de trescientos jabalíes contra solo nosotros tres.

No sea terco, hombre. Aquí no hay jabalíes desde que su abuelo y el mío los exterminaron a pura lanza y cuchillo; hace más de treinta años.

Gerardo Tenorio se sacudió la cara, sin comprender lo que estaba escuchando, y se precipitó por la aldea, que estaba en despojos, tal y como la había encontrado hacía pocas horas, pero no pudo ver los cadáveres por ninguna parte. Dio vuelta redonda a la aldea, y al pasar frente a una de las chozas, vio a dos hombres macilentos que fumaban desdeñosamente. Los hombres le respondieron lo mismo que el hijo de Miranda cuando les contó que había estado peleando con jabalíes la noche anterior. Sintió que los hombres lo miraban con escepticismo y lástima, y vio cómo todas las chozas estaban llenas de un silencio tristísimo, algunas ocupadas solamente por hombres solos, curvados sobre una hamaca y abandonados al sopor del día, rumiando alguna nostalgia fácilmente adivinable en sus rostros. Tenorio se sintió confundido, todavía estaba adormilado y sintió que había tenido tantas alucinaciones que era incapaz de saber si las personas con quienes hablaba eran reales o producto del espejismo que desde hacía rato lo estaba matando. Absorto frente a la aldea, viendo a los hombres fumar con monotonía, sintió la palmada de un hombre joven que le pasaba agua para que se lavara la sangre seca del rostro.

- Dígame que no estoy loco, hijo mío, hijo de mi difunto amigo Miranda, se lo suplico, dígame qué es lo que está pasando-, imploró Tenorio, mientras se secaba la sangre del pómulo.
Aquí no ha pasado nada, amigo -le respondió el hombre-. Aquí no pasa nada desde que las mujeres se tiraron al barranco. Mi padre murió en la guerra, yo casi que ni lo recuerdo. ¿No lo recuerda usted, o es que se está haciendo el loco? Mi padre murió en la guerra y las mujeres se aburrieron de vivir llenas de sarna; se murieron junto a las vacas en el barranco.

Gerardo Tenorio no lo quiso escuchar más. Le dio la espalda y, desconcertado, se encaminó hacia el lugar donde había partido la tarde anterior. Cruzó frente a las chozas y volvió a mirar a los hombres en sus hamacas. Le pareció trágico que la aldea se encontrase tan silente y poblada solo de unos cuantos viejos amodorrados en las soleras de las chozas, devorando el día y cobijados por el sol inmisericorde de Semana Santa. Se volvió a sentir viejo y, al pasar frente a un charco que aún quedaba del aguacero de la mañana, sintió un deseo ubérrimo de beber agua embarrialada, como un legítimo puerco. Se agachó a sorber del charco, y al mirarse en el reflejo vio el rostro mustio y vencido de un viejo poco menos que cadavérico, entristecido, desvencijado. Corrió desesperado en dirección hacia el Cementerio y, justo luego de cruzar el crique, llegó al barranco, jadeando del cansancio.

Allí se precipitaba un abismo abrumador, poblado de una osamenta de vacas que murieron boca arriba. Entrecruzados con la osamenta había huesos de seres humanos, adultos y niños; todos muertos, a juzgar por la ausencia de mal olor, hacía tanto tiempo, que Tenorio prefirió no atormentarse calculando su antigüedad. Miró hacia el horizonte y descubrió que una parvada de zopilotes lo miraba desde lo alto de los espaveles y, entonces, invadido por uno de los últimos terrores que le quedaba por vivir, corrió nuevamente hacia la aldea, incrustado en un laberinto de realidades y alucinaciones que le eran ya imposibles de diferenciar. Había vivido demasiados años en tan solo un día. Había visto todas las alucinaciones que un ser humano puede ver en todos los siglos de miseria de este mundo terrenal y prosaico. Había sentido los alones de la muerte rondarle las espaldas por años, en tan solo una noche, la noche más larga en la milenaria tragedia 
humana: LA INTERMINABLE NOCHE DE LOS JABALÍES. Siguió corriendo a galope hacia la aldea, con la lanza todavía en las manos, y pudo ver centenares de animales degollados, tirados a sus pies, en el callejón todavía cenagoso, y escuchó por última vez la orquesta de voces que no habían parado de asediarlo, como una horda de fantasmas hambrientos.

Del aire rojizo del poniente surgió una mudez sombría, como un cataclismo de negro augurio, que sacó a los aldeanos de su mutismo. Salieron todos, los trece hombres que quedaban en la aldea, desnudos casi, con el sudor todavía bajando a media espalda por el calor que dejó la tarde. Miraron a Tenorio aproximarse a toda carrera hacia el caserío, tambaleándose, casi zigzagueando y dejando un chorrito de sangre en el zacatal seco frente a las chozas. Los hombres le abrieron el paso, estupefactos, y le vieron detenerse frente a la roca donde por largo tiempo estuvo rumiando la tragedia cuando llegó a la aldea luego de la noche de los jabalíes. Vieron que tenía la lanza metida entre el vientre, y por sus pantalones roídos bajaba la sangre casi negra. Tenorio quiso mantenerse en pie para poder disfrutar de ese mareo celestial que invade al alma justo antes de cruzar el Temible Umbral, y se preguntó por qué tarda tanto el hombre en morir, si es la única verdad de todas las verdades que se proclaman en el mundo. Quiso saber las respuestas a tantas preguntas que en vida se había formulado, y se topó con que la verdad de todas esas cosas era algo imposible, a lo que ya no podía ni quería aspirar. Le temblaban las piernas, tenía la mirada nublada, y sentía el vientre lleno de una sensación tan placentera, que le resultó comparable únicamente a la tibiez que experimentaba al poner la mano sobre el cuello gorgoriteante de un jabalí recién acuchillado. Tenorio cayó poco a poco sobre sus rodillas y se curvó levemente hacia atrás, clavando los ojos en las nubes que avanzaban perezosas hacia el oeste.

Gerardo Tenorio supo que la muerte por fin lo había alcanzado. Husmeó suavemente con los dedos bajo su vientre, y acarició la tibiez de la sangre rezumada. Volvió a sentir un ligero mareo, se columpió un poco, y con fuerza bárbara empujó la lanza que tenía ya embutida entre las entrañas, para asegurarse de que esta vez no estuviera dentro de un sueño, y el acero de la hoja traspasó las vísceras, hasta salir como un arpón hambriento sobre su espalda...

$$
* * * * *
$$

En el aire aún silente se escuchaba el Réquiem ronco del curré, que se fue quedando mudo cuando las últimas nubes se fueron tiñendo de un rojo negruzco en las lejanías del poniente. El Volcán lanzó un rugido ciclónico y la tierra soltó un clamor como de madre acuchillada. Luego de un largo tiempo, los hombres regresaron a sus chozas, mudos todavía, por siempre y para siempre, casi desnudos e indiferentes, llenos de soledad y condenación, y se quedaron dormidos eternamente en la lobreguez de sus corazones. Un enorme búho pregonó la llegada de la oscuridad y la aldea se pobló nuevamente de sombras, pues desde aquella noche la tierra del Volcán había condenado a los hombres al impostergable destino de morir solos, como terribles bestias tristes y olvidadas.

\section{(@) $\mathbb{\oplus \Theta \Theta}$}

Este obra está bajo una licencia de Creative Commons 